\title{
Alkyl hydroperoxide reductase enhances the growth of Leuconostoc mesenteroides lactic acid bacteria at low temperatures
}

Seitaro Goto', Jun Kawamoto², Satoshi B Sato ${ }^{3}$, Takashi Iki', Itaru Watanabe', Kazuyuki Kudo', Nobuyoshi Esaki ${ }^{2}$ and Tatsuo Kurihara ${ }^{2 *}$

\begin{abstract}
Lactic acid bacteria (LAB) can cause deterioration of food quality even at low temperatures. In this study, we investigated the cold-adaptation mechanism of a novel food spoilage LAB, Leuconostoc mesenteroides NH04 (NH04). L. mesenteroides was isolated from several spoiled cooked meat products at a high frequency in our factories. $\mathrm{NH04}$ grew rapidly at low temperatures within the shelf-life period and resulted in heavy financial losses. NH04 grew more rapidly than related strains such as Leuconostoc mesenteroides NBRC3832 (NBRC3832) at $10^{\circ} \mathrm{C}$. Proteome analysis of $\mathrm{NHO4}$ demonstrated that this strain produces a homolog of alkyl hydroperoxide reductase--AhpC--the expression of which can be induced at low temperatures. The expression level of AhpC in NH04 was approximately 6-fold higher than that in NBRC3832, which was grown under the same conditions. Although AhpC is known to have an anti-oxidative role in various bacteria by catalyzing the reduction of alkyl hydroperoxide and hydrogen peroxide, the involvement of AhpC in cold adaptation of food spoilage bacteria was unclear. We introduced an expression plasmid containing ahpC into NBRC3832, which grows slower than $\mathrm{NHO4}$ at $10^{\circ} \mathrm{C}$, and found that expression of AhpC enhanced growth. These results demonstrated that AhpC, which likely increases anti-oxidative capacity of $L A B$, plays an important role in their rapid growth at low temperatures.
\end{abstract}

Keywords: Lactic acid bacteria; Food spoilage; Cold adaptation; AhpC

\section{Introduction}

Lactic acid bacteria (LAB) are useful for the production of fermented foods such as soy sauce and cheese (Caplice and Fitzgerald 1999; McKay and Baldwin 1990; Murooka and Yamshita 2008). Although the importance of LAB is widely recognized, LAB sometimes cause quality defects in fresh foods and fermented meat products stored at low temperatures (Borch et al. 1996). LAB that cause food spoilage can grow and cause quality defects by producing an unpleasant taste, white liquid, and a slimy substance (Asano et al. 2009; Hamasaki et al. 2003; Kondo and Ikeda 2000) even in cooked meat products such as ham and sausage stored at $10^{\circ} \mathrm{C}$. Therefore, to ensure the safety of stored food and reduce such risks, elucidation of the cold-adaptation mechanism of LAB in food products is important. LAB that are closely

\footnotetext{
* Correspondence: kurihara@scl.kyoto-u.ac.jp

${ }^{2}$ Institute for Chemical Research, Kyoto University, Uji, Kyoto 611-0011, Japan Full list of author information is available at the end of the article
}

related to Leuconostoc mesenteroides, Lactococcus lactis, Leuconostoc citreum, and Weissella viridescens grow rapidly at temperatures below $10^{\circ} \mathrm{C}$ (Borch et al. 1996; Chenoll et al. 2007; Diez et al. 2009; Hamasaki et al. 2003; Metaxopoulos et al. 2002; Samelis et al. 2006; Samelis et al. 1998), and are frequently isolated from spoiled cooked meat products stored at $10^{\circ} \mathrm{C}$. These findings suggest a unique system of adaptation to low temperatures, causing rapid food spoilage in the refrigerator.

At low temperatures, microbes must overcome unfavorable conditions such as decreased membrane fluidity, molecular dynamics, and enzymatic activities. They can adapt to such an extreme environment via the induction of cold-shock and cold-acclimation proteins responsible for the maintenance of membrane fluidity, protein synthesis and folding, and metabolism (Feller and Gerday 2003; Graumann and Marahiel 1998; Marceau et al. 2004; Salotra et al. 1995; Wang et al. 2005; Wouters et al. 2000; Yamanaka et al. 1998). Identification 
and characterization of these proteins is necessary to understand the environmental adaptations of psychrotrophic LAB. Many studies on cold-inducible proteins have been reported, but few have focused on the relationship between these proteins and the growth of food spoilage bacteria. In order to prevent the contamination of foods by psychrotrophic LAB and to develop a method for their detection, we focused on the cold-adaptation mechanism of $\mathrm{LAB}$ at the molecular level. In this study, we characterized a novel psychrotrophic LAB, Leuconostoc mesenteroides NH04 (NH04), isolated from cooked meat stored at $10^{\circ} \mathrm{C}$. L. mesenteroides was isolated from several spoiled cooked meat products at high frequency in our factories. $\mathrm{NH04}$ grows rapidly at low temperatures within the shelf-life period and is responsible for the significant financial losses incurred. We analyzed the proteins that were inducibly expressed by this strain at low temperatures and identified a protein that facilitates the growth of $L$. mesenteroides at low temperatures.

\section{Materials and methods}

Bacterial strains, plasmids, and culture conditions

The strains used in this study are NH04 isolated from spoiled sausage and the related LAB, Leuconostoc mesenteroides NBRC3832 (NBRC3832) (NITE Biological Resource Center; Kisarazu, Japan). NH04 was deposited in NITE Biological Resource Center with accession number NBRC110676. For isolation of NH04, $25 \mathrm{~g}$ of spoiled product was suspended in $225 \mathrm{~mL}$ saline, and the suspension was subjected to 10 -fold serial dilution. The dilutions $(1 \mathrm{~mL})$ were mixed with $15-20 \mathrm{~mL}$ BCP medium containing agar (Nissui Pharmaceutical Co., Ltd.; Tokyo, Japan), and the plates were incubated at $25^{\circ} \mathrm{C}$ for $72 \mathrm{~h}$. The dominant species in the plates were isolated, and identified by sequencing their $16 \mathrm{~S}$ rRNA genes. The nucleotide sequence of the $16 \mathrm{~S}$ rRNA gene of NH04 was deposited in DDBJ with accession number LC005518. NH04 thus isolated and NBRC3832 were grown in $5 \mathrm{~mL}$ GAM broth (Nissui Pharmaceutical Co., Ltd.), with 1.0\% D-glucose added to improve LAB growth. GAM broth consisted of peptone (10.0 g), soy peptone $(3.0 \mathrm{~g})$, proteose peptone $(10.0 \mathrm{~g})$, digested serum $(13.5 \mathrm{~g})$, yeast extract $(5.0 \mathrm{~g})$, meat extract $(2.2 \mathrm{~g})$, liver extract $(1.3 \mathrm{~g})$, dextrose $(3.0 \mathrm{~g})$, potassium dihydrogen phosphate $(2.5 \mathrm{~g})$, sodium chloride $(3.0 \mathrm{~g})$, soluble starch $(5.0 \mathrm{~g})$, L-cysteine hydrochloride ( $2.5 \mathrm{~g})$, and sodium thioglycolate $(0.3 \mathrm{~g})$ dissolved in $1 \mathrm{~L}$ of deionized water (final $\mathrm{pH}$ of 7.1). The cells were grown at $10^{\circ} \mathrm{C}$ or $25^{\circ} \mathrm{C}$ in a compact rocking incubator (TVS062CA; ADVANTEC Toyo; Tokyo, Japan) by shaking at $70 \mathrm{rpm}$, and the growth was simultaneously monitored by measuring the turbidity at $660 \mathrm{~nm}$ with a spectrophotometer installed in the incubator. The kinetics of the growth was determined from three independent experiments. The LAB shuttle vector pGK::nucMCS (Le Loir et al. 1994) was used for the transformation of NBRC3832. Transformants harboring pGK::nucMCS and pGKahpC, which was constructed as described below, were cultivated in the presence of erythromycin $(5 \mu \mathrm{g} / \mathrm{mL})$.

\section{Identification of cold-inducible proteins by two-dimensional electrophoresis (2DE)}

Cells $(10 \mathrm{~mL})$ grown to stationary phase $\left(1.5<\mathrm{OD}_{600}<2.5\right)$ at $10^{\circ} \mathrm{C}$ and $25^{\circ} \mathrm{C}$ were harvested by centrifugation and resuspended in $100 \mu \mathrm{l}$ of $50 \mathrm{mM}$ Tris- $\mathrm{HCl}(\mathrm{pH}$ 7.0). Cell suspensions were sonicated for $50 \mathrm{~min}$ at $10 \%$ amplitude (3 mm microtip, $400 \mathrm{~W}$; Digital Sonifier; BRANSON Ultrasonics Corporation; Danbury, CT) while they were chilled on ice, and then centrifuged at $2,200 \times g$ for $10 \mathrm{~min}$ at $4^{\circ} \mathrm{C}$. Proteins in the supernatants were purified using the ReadyPrep 2-D Cleanup Kit (Bio-Rad Laboratories, Inc.; Hercules, CA) before an initial isoelectric focusing. Proteins $(150 \mu \mathrm{g})$ were loaded onto Ready Strip IPG strips (17 cm, pH 4-7; Bio-Rad Laboratories, Inc.), and isoelectric focusing was performed using the PROTEAN IEF Cell (Bio-Rad Laboratories, Inc.), according to the manufacturer's protocol. Treatment of the gel strips for 2DE was carried out as described previously (Kawamoto et al. 2007). After fixation and staining with SYPRO Ruby (Invitrogen Corp.; Carlsbad, CA), gels were scanned using Typhoon 9400 image analyzer (GE Healthcare Ltd.; Buckinghamshire, UK). Each experiment was performed three times to ensure reproducibility.

$\mathrm{N}$-Terminal amino acid sequence of the protein inducibly produced at $10^{\circ} \mathrm{C}$ was determined using a PPSQ-21 protein sequencer (Shimadzu; Kyoto, Japan). A BLAST search (http://blast.ncbi.nlm.nih.gov/Blast.cgi) with the identified $\mathrm{N}$-terminal sequence suggested that the cold-inducible protein was a homolog of AhpC. Degenerate primers for amplification of the $a h p C$ gene of NH04 [peroxi130_For and peroxi569_Rev (Table 1)] were designed from conserved regions of the genes coding for AhpC from several LAB, including Leuconostoc, Lactobacillus, and

\begin{tabular}{ll}
\multicolumn{2}{l}{ Table 1 Primers used in this study } \\
\hline Primer & Sequence \\
\hline peroxi130_For & GACTTCTCATTTGTTGYCC \\
peroxi569_Rev & TAMAKYTTRCCRACTARRTCWARRCT \\
peroxi232_inv_For & GTATCCGTAGCTTCTGCC \\
peroxi407_inv_Rev & CATATACCATCAACAACATGGG \\
peroxi_start_For & ATGACTACAAATTTATTGATTCAGAAATAACAGA \\
peroxi_End_Sall_Rev & ACGCGTCGACGTCCTAAATTTACCAACTAAATCT \\
& AAGCTCG \\
thr_prm_Xhol_For & CCGCTCGAGCGGATCATCTGATAGATATCGATCA \\
& TAAGAG \\
thr_prm_peroxi_Rev & TCAATAAAATTGTAGTCATGATTAATTCTCCTTIT \\
& TGTGACAAAAGTA \\
\hline
\end{tabular}


Enterococcus species, and the internal nucleotide fragment was amplified. Based on the internal sequence of the gene coding for $\mathrm{AhpC}$ in $\mathrm{NH04}$, an inverse PCR was performed with two primers (peroxi232_inv_For and peroxi407_inv_Rev) listed in Table 1. The sequences of the PCR products were determined and assembled to obtain the complete sequence of $a h p C$, which was deposited in DDBJ with accession number AB819067.

\section{RNA extraction and quantitative real-time RT-PCR}

Total RNA was extracted from cells cultivated at $10^{\circ} \mathrm{C}$ and $25^{\circ} \mathrm{C}$ using the RNeasy Kit (QIAGEN Inc., Valencia, CA). RNA pellets were dissolved in $0.1 \%$ diethyl pyrocarbonatetreated water and stored at $-80^{\circ} \mathrm{C}$ until use. Quantitative real-time RT-PCR was performed with SuperScript III Platinum SYBR Green One-Step qRT-PCR Kit (Invitrogen Corp.) and an Mx3000P Multiple Quantitative RT-PCR system (Stratagene; La Jolla, CA). The amount of mRNA in each sample was normalized with the amount of $16 \mathrm{~S}$ rRNA. Each experiment was performed three times to ensure reproducibility.

\section{Construction of AhpC-overexpressing strain}

A gene fragment coding for AhpC was amplified using the primers peroxi_start_For and peroxi_end_SalI_Rev (Table 1), and the PCR product was fused with a DNA fragment containing a putative promoter region of the NH04 mannitol dehydrogenase gene $(m d h)$ amplified by PCR with the primers thr_prm_XhoI_For and thr_prm_peroxi_Rev. The gene fragment was ligated with the pGK::nucMCS plasmid after digestion with XhoI and SalI. The constructed plasmid, pGKahpC, was introduced into NBRC3832 and NH04 by electroporation. Electroporation was performed using a previously described method with slight modifications (Leathers et al. 2004). Briefly, the cells from $50 \mathrm{~mL}$ culture were harvested at an $\mathrm{OD}_{600}$ of 0.6 , washed twice with $75 \mathrm{~mL}$ of ice-cold deionized water, then washed once with $5 \mathrm{~mL}$ of ice-cold sterile electroporation buffer ( $1 \mathrm{mM}$ of potassium phosphate buffer ( $\mathrm{pH}$ 7.4) containing $1 \mathrm{mM}$ of $\mathrm{MgCl}_{2}$ and $0.5 \mathrm{M}$ of sucrose), and suspended in $1 \mathrm{~mL}$ of electroporation buffer. Plasmids $(1 \mu \mathrm{g})$ were mixed with $40 \mu \mathrm{L}$ of the cell suspensions and placed into a pre-chilled electroporation cuvette $(0.2 \mathrm{~cm})$. Electroporation was performed with the Gene Pulser Xcell PC system (Bio-Rad Laboratories, Inc.) at a capacitance of $25 \mu \mathrm{F}$. After electroporation, the cell suspensions were immediately diluted with $1 \mathrm{~mL}$ of GAM broth containing 1\% D-glucose and incubated at $25^{\circ} \mathrm{C}$ for $2 \mathrm{~h}$. Transformants were selected on GAM plates containing 1\% D-glucose and $5 \mu \mathrm{g} / \mathrm{mL}$ of erythromycin.

Production of AhpC from NH04 was analyzed by SDS-PAGE. SDS-PAGE was performed on a $12.5 \%$ polyacrylamide gel (ePAGEL; ATTO Corp.; Tokyo, Japan). Soluble proteins $(5 \mu \mathrm{g})$ were loaded and run on the gel. After fixation and staining with SYPRO Ruby, the gels were scanned using a Typhoon 9400 imager.

\section{Results \\ Growth of NHO4}

The growth of NH04 and NBRC3832 at $10^{\circ} \mathrm{C}$ and $25^{\circ} \mathrm{C}$ was monitored. NH04 grew faster than NBRC3832 at both $10^{\circ} \mathrm{C}$ and $25^{\circ} \mathrm{C}$ (Figure 1a, b). The doubling times of $\mathrm{NH} 04$ were $9 \pm 0.6 \mathrm{~h}$ and $1.8 \pm 0.1 \mathrm{~h}$ at $10^{\circ} \mathrm{C}$ and $25^{\circ} \mathrm{C}$, respectively, whereas those of NBRC3832 were $13 \pm 0.7 \mathrm{~h}$ and $2.5 \pm 0.3 \mathrm{~h}$ at $10^{\circ} \mathrm{C}$ and $25^{\circ} \mathrm{C}$, respectively. These results indicate that there were significant differences $(p<0.05, \mathrm{n}=3)$ between the doubling times of the two strains at both $10^{\circ} \mathrm{C}$ and $25^{\circ} \mathrm{C}$.

\section{Identification of the cold-inducible protein of cold-adapted Leuconostoc mesenteroides $\mathrm{NHO4}$}

To identify the proteins contributing to the cold adaptation of $\mathrm{NH} 04$, we performed 2DE of the soluble proteins of $\mathrm{NH} 04$ grown at $10^{\circ} \mathrm{C}$ and $25^{\circ} \mathrm{C}$. $2 \mathrm{DE}$ analysis showed that the amount of a specific protein, indicated by arrowhead in
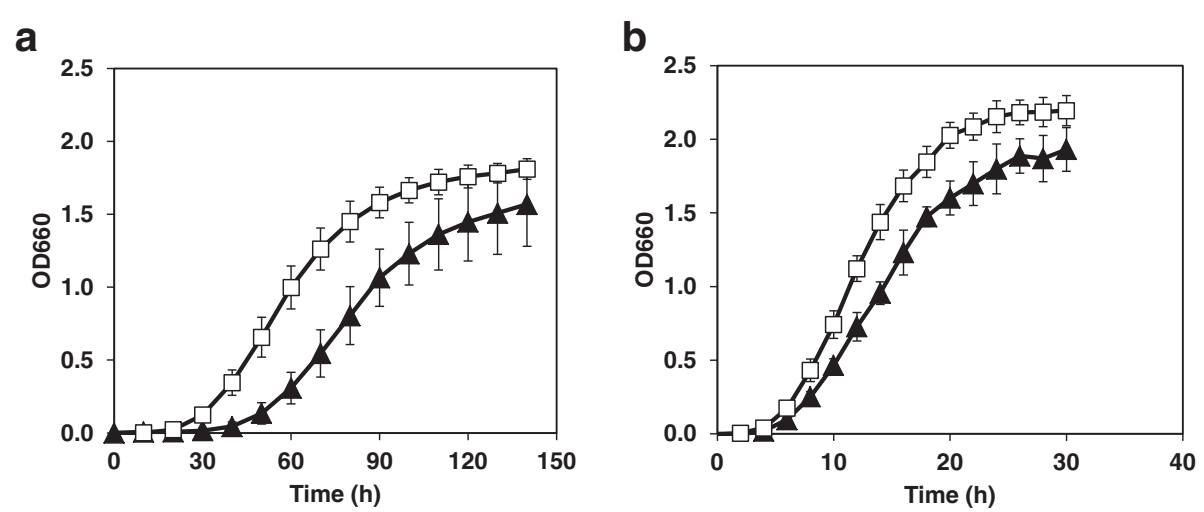

Figure 1 Growth of NHO4 and NBRC3832. NHO4 (square) and NBRC3832 (triangle) were cultured at $10^{\circ} \mathrm{C}$ (a) and $25^{\circ} \mathrm{C}$ (b). Each growth curve was plotted using data obtained from three experiments. 
Figure $2 \mathrm{a}$ and $\mathrm{b}$, was $2 \pm 0.2$ times higher $(p<0.05, \mathrm{n}=3)$ in the cells grown at $10^{\circ} \mathrm{C}$ than in the cells grown at $25^{\circ} \mathrm{C}$. We further characterized this protein because it was one of the major proteins of $\mathrm{NH} 04$ and reproducibly more abundant at $10^{\circ} \mathrm{C}$. The $\mathrm{N}$-terminal amino acid sequence of this protein was MTTNFIDSEITDFKVNAYHD. The gene encoding this protein was cloned and sequenced as described in Materials and Methods, and it was found that this cold-inducible protein was a homolog of alkyl hydroperoxide reductase (AhpC). The $a h p C$ gene (AB819067) coded for a protein of 189 amino acid residues, and the calculated molecular weight of the protein was 21,118.5. AhpC of NH04 shares a high sequence similarity $(99.5 \%$ identity) with that of NBRC3832 (AB921977). Despite the high sequence similarity, the expression level of this protein was much higher in NH04 than in NBRC3832. 2DE analysis of the soluble proteins of NBRC3832 grown under the same conditions demonstrated that the fluorescence intensity of the spot for AhpC (arrowhead in Figure 2c) was approximately $17 \% \pm 12 \%$ of that for NH04 (arrowhead in Figure 2a).

\section{Transcriptional levels of $a h p C$ in Leuconostoc species}

The transcriptional level of $a h p C$ in the NH04 cells grown at $10^{\circ} \mathrm{C}$ was approximately $3.8 \pm 1.5$-fold greater $(p<0.05, \mathrm{n}=3)$ than that in the cells grown at $25^{\circ} \mathrm{C}$. The level of $a h p C$ in $\mathrm{NH} 04$ grown at $10^{\circ} \mathrm{C}$ was approximately $2.8 \pm 0.4$-fold higher $(p<0.05, \mathrm{n}=3)$ than that in NBRC3832 grown under the same conditions.

\section{AhpC facilitates the growth of LAB at low temperatures}

To examine the effects of high-level expression of AhpC on the growth of LAB at low temperatures, we constructed an overexpression vector for $a h p C$ (pGKahpC) and introduced it into NBRC3832, which grows slower than NH04. The level of AhpC in NBRC3832 harboring pGKahpC was approximately $6.5 \pm 1$.6-fold higher than that in the cells harboring a control plasmid, pGK:: nucMCS (Figure 3a). NBRC3832 overexpressing ahpC grew more rapidly than the cells containing a control plasmid at $10^{\circ} \mathrm{C}$ (Figure 3b). The doubling time of NBRC3832 harboring pGKahpC was $15.4 \pm 0.8 \mathrm{~h}$, whereas that of the strain harboring pGK::nucMCS was $17.6 \pm 1.1 \mathrm{~h}$. The difference between the growth rates of NBRC3832 harboring pGKahpC and pGK::nucMCS was statistically significant $(p<0.05, \mathrm{n}=3)$. In contrast to the case of NBRC3832, the growth rate of NH04 was not affected by introduction of pGKahpC (Figure 3b). The doubling times of $\mathrm{NH} 04$ harboring pGKahpC and pGK::nucMCS were both $9.8 \pm 0.3 \mathrm{~h}$ at $10^{\circ} \mathrm{C}$. At $25^{\circ} \mathrm{C}$, introduction of pGKahpC did not significantly affect the growth rate of NBRC3832 and NH04 (data not shown). The doubling times of NBRC3832 harboring pGKahpC
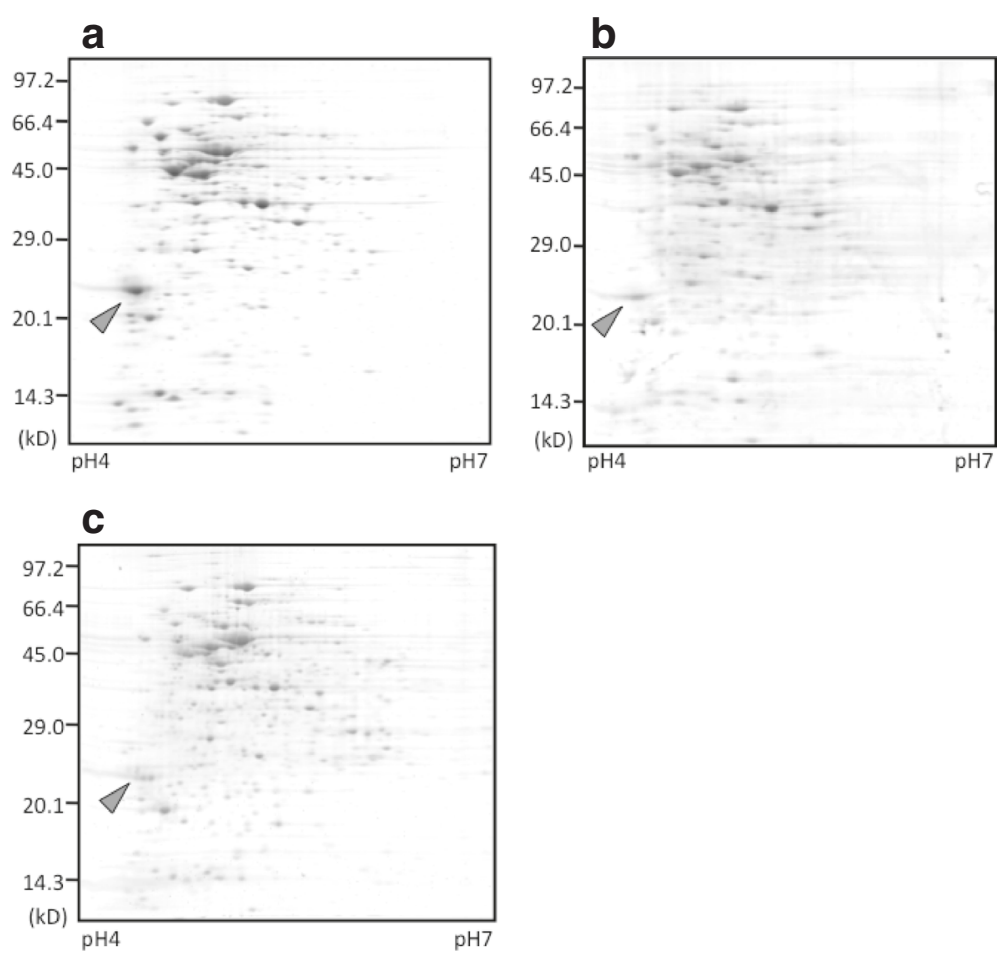

Figure 2 Two-dimensional polyacrylamide gel electrophoresis of soluble proteins extracted from $\mathrm{NH} 04$ grown at $10^{\circ} \mathrm{C}(\mathrm{a})$ and $25^{\circ} \mathrm{C}(\mathrm{b})$ and the related strain, NBRC3832, grown at $10^{\circ} \mathrm{C}$ (c). Arrowhead indicates the spot corresponding to AhpC. 


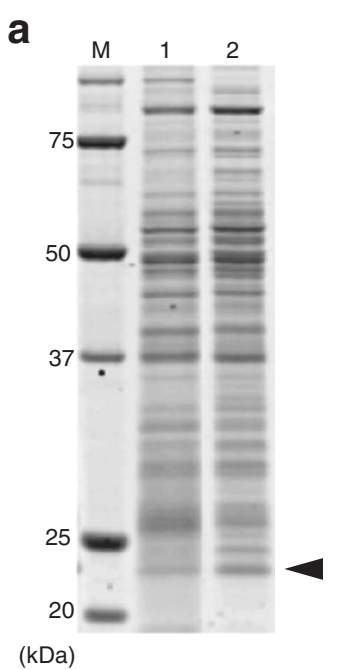

b

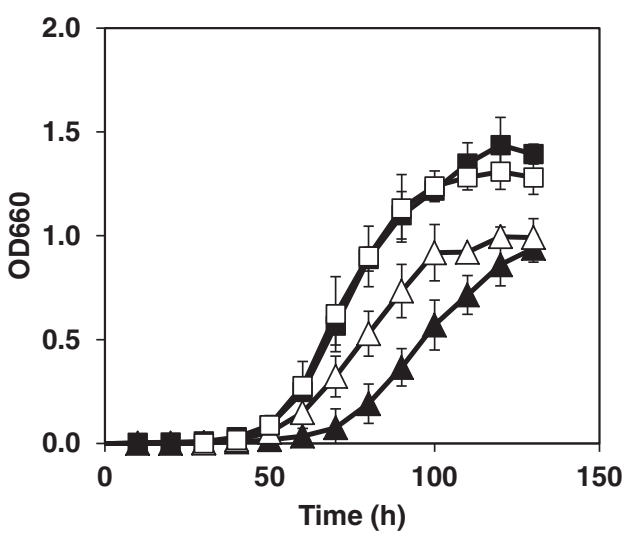

Figure 3 Effects of $a h p C$ overexpression on the growth of NBRC3832. (a) Production of AhpC from NH04 in NBRC3832. Soluble proteins from NBRC3832 harboring a control plasmid (lane 1) and an ahpC overexpression plasmid (lane 2) were analyzed by SDS-PAGE. Arrowhead indicates the band corresponding to AhpC. Lane M represents the molecular weight marker. (b) Growth of NH04 (square) and NBRC3832 (triangle) containing a control plasmid (filled symbol) and an ahpC overexpression plasmid (open symbol) at $10^{\circ} \mathrm{C}$. Each growth curve was plotted using data obtained from three experiments.

and pGK::nucMCS were $3.0 \pm 0.2 \mathrm{~h}$ and $3.2 \pm 0.1 \mathrm{~h}$, respectively, at $25^{\circ} \mathrm{C}$, which were not significantly different from each other $(p<0.05, \mathrm{n}=3)$. The doubling times of NH04 harboring pGKahpC and pGK::nucMCS were both $2.0 \pm 0.1 \mathrm{~h}$ at $25^{\circ} \mathrm{C}$.

\section{Discussion}

We isolated a novel food-spoilage bacterium, NH04, from spoiled meat product at $10^{\circ} \mathrm{C}$, which causes food quality defects at low temperatures. Although little is known regarding the effects of various stresses on Leuconostoc species, they can survive in unfavorable environments such as oxidative and low temperature conditions (Con and Seamus 1986; Salotra et al. 1995; van de Guchte et al. 2002). Most Leuconostoc strains grow even at $10^{\circ} \mathrm{C}$, and $\mathrm{NH} 04$ grows faster than other related strains at both $10^{\circ} \mathrm{C}$ and $25^{\circ} \mathrm{C}$ (Figure 1).

A comprehensive analysis of proteins synthesized in NH04 demonstrated that this strain inducibly produces a homolog of alkyl hydroperoxide reductase, AhpC, which likely has a role in anti-oxidative functions at low temperatures (Figure 2). AhpC homologs are widely distributed among prokaryotes, and $\mathrm{AhpC}$ shares approximately $40 \%$ amino acid sequence identity with thioredoxin peroxidase from yeast, rat, plant, amoebae, nematodes, rodents, and humans (Chen et al. 1998). AhpC homologs define a large family of anti-oxidants present in organisms from all kingdoms, and they protect cells from reactive oxygen species (ROS). ROS such as $\mathrm{O}_{2}^{-}, \cdot \mathrm{OH}$, and $\mathrm{H}_{2} \mathrm{O}_{2}$ cause oxidative damage to cells (Cabiscol et al. 2000). The $\mathrm{O}_{2}^{-}$generated during cell growth is typically converted to hydrogen peroxide spontaneously or by the activity of superoxide dismutase (SOD), from which the hydroxyl radical is generated by a metal-catalyzed redox reaction (the Fenton reaction). Hydroxyl radicals react immediately with cellular components and generate organic hydroperoxide $(\mathrm{ROOH})$ that causes cell damage. AhpC catalyzes the reduction of organic hydroperoxide and protects cell components, thus acting as an anti-oxidant against hydroxyl radicals. Since cold stress induces production of ROS (Gocheva et al. 2009), psychrotrophic LAB that induce the expression of anti-oxidative protein(s) may grow rapidly at low temperatures. We demonstrated that the production of $\mathrm{AhpC}$ from $\mathrm{NHO4}$ in the related strain, NBRC3832, promotes growth at low temperatures (Figure 3). This suggests an important role for AhpC in the growth of LAB at low temperatures. Reduction of organic hydroperoxide may be crucial for LAB to grow at low temperatures. $\mathrm{NH04}$ grows faster than NBRC3832 not only at $10^{\circ} \mathrm{C}$ but also at $25^{\circ} \mathrm{C}$. However, the faster growth of $\mathrm{NH} 04$ at $25^{\circ} \mathrm{C}$ is not likely due to $\mathrm{AhpC}$, because the expression level of $\mathrm{AhpC}$ in $\mathrm{NH} 04$ at $25^{\circ} \mathrm{C}$ is much lower than at $10^{\circ} \mathrm{C}$ and a statistically significant growth improvement of NBRC3832 by overexpression of AhpC was not observed at $25^{\circ} \mathrm{C}$.

In this study, due to the lack of a gene disruption system for $\mathrm{NH04}$ and related strains, the involvement of AhpC in the cold adaptation of NH04 could not be shown directly by a loss-of-function analysis. Nevertheless, the results obtained by heterologous expression of AhpC in a related strain strongly support the view that this protein is involved in the growth of LAB at low temperatures. 
Our results provide new insight into the molecular mechanism of cold adaptation of food-spoilage LAB that cause food quality defects during cold storage. In the future studies, we will examine whether AhpC is involved in the cold adaptation of other food-spoilage $\mathrm{LAB}$, and whether other anti-oxidative substances play a role in cold adaptation. Our findings raise a possibility for the control of food-spoilage related LAB growing at low temperatures by developing an inhibitor against their antioxidation system. It may also be possible in the future for food manufacturers to detect food products and manufacturing equipment contaminated with food-spoilage $\mathrm{LAB}$ by developing a system to detect $\mathrm{AhpC}$ as a marker.

\section{Competing interests}

The authors declare that they have no competing interests.

\section{Authors' contributions}

SG designed the study, performed all the experiments, and wrote the manuscript. JK designed the study, helped the experiments, and wrote the manuscript. SBS helped experimental design and participated in the discussion on the interpretation of the results. TI, IW, and KK were committed to all the experiments. NE participated in the discussion on the interpretation of the results. TK designed the study and wrote the manuscript. All authors approved the final manuscript.

\section{Acknowledgments}

This work was supported in part by Grants-in-Aid for Scientific Research (B) from JSPS (22404021, 24380047, and 25303028 to T.K.) and a Grant from the Japan Foundation for Applied Enzymology (to T.K.).

\section{Author details}

${ }^{1}$ Product Development Laboratory, NH Foods Ltd., Chikusei, Ibaraki 308-0042, Japan. ${ }^{2}$ Institute for Chemical Research, Kyoto University, Uji, Kyoto 611-0011, Japan. ${ }^{3}$ Research Center for Low Temperature and Materials Sciences, Kyoto University, Kyoto 606-8501, Japan.

Received: 11 October 2014 Accepted: 20 January 2015

Published online: 18 February 2015

\section{References}

Asano S, lijima K, Suzuki K, Motoyama Y, Ogata T, Kitagawa Y (2009) Rapid detection and identification of beer-spoilage lactic acid bacteria by microcolony method. J Biosci Bioeng 108(2):124-129, doi:10.1016/j.jbiosc.2009.02.016

Borch E, Kant-Muermans ML, Blixt Y (1996) Bacterial spoilage of meat and cured meat products. Int J Food Microbiol 33(1):103-120, doi:10.1016/0168-1605(96)01135-X

Cabiscol E, Tamarit J, Ros J (2000) Oxidative stress in bacteria and protein damage by reactive oxygen species. Int Microbiol 3(1):3-8

Caplice E, Fitzgerald GF (1999) Food fermentations: role of microorganisms in food production and preservation. Int J Food Microbiol 50(1-2):131-149, doi:10.1016/S0168-1605(99)00082-3

Chen L, Xie QW, Nathan C (1998) Alkyl hydroperoxide reductase subunit C (AhpC) protects bacterial and human cells against reactive nitrogen intermediates. Mol Cell 1(6):795-805, doi: 10.1016/S1097-2765(00)80079-9

Chenoll E, Macian MC, Elizaquivel P, Aznar R (2007) Lactic acid bacteria associated with vacuum-packed cooked meat product spoilage: population analysis by rDNA-based methods. J Appl Microbiol 102(2):498-508, doi:10.1111/j.13652672.2006.03081.x

Con AL, Seamus EC (1986) Active role of oxygen and NADH oxidase in growth and energy metabolism of Leuconostoc. J Gene Microbiol 132(7):1789-1796, doi:10.1099/00221287-132-7-1789

Diez AM, Bjorkroth J, Jaime I, Rovira J (2009) Microbial, sensory and volatile changes during the anaerobic cold storage of morcilla de Burgos previously inoculated with Weissella viridescens and Leuconostoc mesenteroides. Int J Food Microbiol 131(2-3):168-177, doi:10.1016/j.ijfoodmicro.2009.02.019

Feller G, Gerday C (2003) Psychrophilic enzymes: hot topics in cold adaptation. Nat Rev Microbiol 1(3):200-208, doi:10.1038/nrmicro773
Gocheva YG, Tosi S, Krumova ET, Slokoska LS, Miteva JG, Vassilev SV, Angelova MB (2009) Temperature downshift induces antioxidant response in fungi isolated from Antarctica. Extremophiles 13(2):273-281, doi:10.1007/s00792008-0215-1

Graumann PL, Marahiel MA (1998) A superfamily of proteins that contain the cold-shock domain. Trends Biochem Sci 23(8):286-290, doi:10.1016/S09680004(98)01255-9

Hamasaki Y, Ayaki M, Fuchu H, Sugiyama M, Morita H (2003) Behavior of psychrotrophic lactic acid bacteria isolated from spoiling cooked meat products. Appl Environ Microbiol 69(6):3668-3671, doi:10.1128/ AEM.69.6.3668-3671.2003

Kawamoto J, Kurihara T, Kitagawa M, Kato I, Esaki N (2007) Proteomic studies of an Antarctic cold-adapted bacterium, Shewanella livingstonensis Ac10, for global identification of cold-inducible proteins. Extremophiles 11(6):819-826, doi:10.1007/s00792-007-0098-6

Kondo T, Ikeda T (2000) Rapid detection of substrate-oxidizing activity of hiochi bacteria using benzoquinone-mediated amperometric method. J Biosci Bioeng 90(2):217-219, doi:10.1016/S1389-1723(00)80114-0

Le Loir Y, Gruss A, Ehrlich SD, Langella P (1994) Direct screening of recombinants in Gram-positive bacteria using the secreted staphylococcal nuclease as a reporter. J Bacteriol 176(16):5135-5139

Leathers TD, Jones JD, Wyckoff HA (2004) Transformation of alternan-producing strains of Leuconostoc by electroporation. Biotechnol Lett 26(14):1119-1124, doi:10.1023/B:BILE.0000035482.41491.7e

Marceau A, Zagorec M, Chaillou S, Mera T, Champomier-Verges MC (2004) Evidence for involvement of at least six proteins in adaptation of Lactobacillus sakei to cold temperatures and addition of $\mathrm{NaCl}$. Appl Environ Microbiol 70 (12):7260-7268, doi:10.1128/AEM.70.12.7260-7268.2004

McKay LL, Baldwin KA (1990) Applications for biotechnology: present and future improvements in lactic acid bacteria. FEMS Microbiol Rev 7(1-2):3-14, doi:10.1016/0378-1097(90)90694-L

Metaxopoulos J, Mataragas M, Drosinos EH (2002) Microbial interaction in cooked cured meat products under vacuum or modified atmosphere at $4^{\circ} \mathrm{C}$. J Appl Microbiol 93(3):363-373, doi:10.1046/j.1365-2672.2002.01701.x

Murooka Y, Yamshita M (2008) Traditional healthful fermented products of Japan. J Ind Microbiol Biotechnol 35(8):791-798, doi:10.1007/s10295-008-0362-5

Salotra P, Singh DK, Seal KP, Krishna N, Jaffe H, Bhatnagar R (1995) Expression of DnaK and GroEL homologs in Leuconostoc esenteroides in response to heat shock, cold shock or chemical stress. FEMS Microbiol Lett 131(1):57-62, doi:10.1111/j.1574-6968.1995.tb07754.x

Samelis J, Bjorkroth J, Kakouri A, Rementzis J (2006) Leuconostoc carnosum associated with spoilage of refrigerated whole cooked hams in Greece. J Food Prot 69(9):2268-2273

Samelis J, Kakouri A, Georgiadou KG, Metaxopoulos J (1998) Evaluation of the extent and type of bacterial contamination at different stages of processing of cooked ham. J Appl Microbiol 84(4):649-660, doi:10.1046/j.1365-2672.1998.00392.x

van de Guchte M, Serror P, Chervaux C, Smokvina T, Ehrlich SD, Maguin E (2002) Stress responses in lactic acid bacteria. Antonie Van Leeuwenhoek 82(1-4):187-216, doi:10.1023/A:1020631532202

Wang Y, Delettre J, Guillot A, Corrieu G, Beal C (2005) Influence of cooling temperature and duration on cold adaptation of Lactobacillus acidophilus RD758. Cryobiology 50(3):294-307, doi:10.1016/j.cryobiol.2005.03.001

Wouters JA, Mailhes M, Rombouts FM, de Vos WM, Kuipers OP, Abee T (2000) Physiological and regulatory effects of controlled overproduction of five cold shock proteins of Lactococcus lactis MG1363. Appl Environ Microbiol 66 (9):3756-3763, doi:10.1128/AEM.66.9.3756-3763.2000

Yamanaka K, Fang L, Inouye M (1998) The CspA family in Escherichia coli: multiple gene duplication for stress adaptation. Mol Microbiol 27(2):247-255, doi:10.1046/j.1365-2958.1998.00683.x 